\title{
From the Separate International Agreements to the Balkan Common Approach: Achievements and Challenges
}

Fejzi LILA

$\mathrm{PhD}$ candidate, European University of Tirana, Albania

\begin{abstract}
The end of the Cold War brought a lot of complication in the Balkans. The centre of problem was former Yugoslavia. The Federation faced political, ethnical end socio-economical challenges. The conflict exploded into bloody war. In order to bring the conflict to the end IC intervened end signed international agreements. The challenges remain these agreements to be implemented.
\end{abstract}

Keywords: Cold War, international agreements, political end ethnical conflict, implementation.

\section{Introduction}

After the Cold War the Eastern European Countries were willingly involved in general reforms to transform the previous communist regime into the democratic one. Western democratic system served as the model that inspired the peoples and the countries of Eastern Europe in order democratic values to be absorbed, standards to be achieved and criteria to be met by all of them in very limited time.

Despite of this very progressive process the Balkan Region faced extremely contradictory situation. From 1991 to 2008 the entire Region were characterized by inter-state and intra-state conflicts and wars. A very bloody fragmentation process started with the dissolution of Former Yugoslavia Federation and several political troubles, ethnic cleansing and social unrest took place in Countries around the conflict areas. So, the entire Balkans repeated bed-famed history as the "Powder Ked".

There were not political will and human energies within the Balkan prevent and to resolve the crises by themselves. It was very active International Community intervention by all ways and means, from diplomatic efforts to military strike to bring this deep, complex and bloody crisis to the end. All of us should pay tribute to the USA, NATO 1 , UN², OSCE ${ }^{3}, \mathrm{EU}^{4}, \mathrm{CE}^{5}$ and to innumerable Regional Initiatives like Stability Pact ${ }^{6}$, SEEI, BSEC, CEI, Adriatic Ionian Initiative, Adriatic-Charter ${ }^{7}$ that created the different environment for the Balkans.

As it always happened during the history the wars and conflicts come to the end through peace treaties, peace-agreements or other documents that create the legal framework for the crisis resolution and post crisis reconstruction. The Balkan last crisis was not excluded from this historical heritage. There for "Dayton Peace Accord" (1995), "Ohrid Framework Agreement" (2001) and "Document for Kosovo" 2007, known as "Ahtisari Proposal" created the fundamental legal framework for crisis resolution and post-crisis reconstruction in the Former Yugoslavia area.

There is no doubt that these three main International Agreements were extraordinary contributions by International Community to influence the Balkans to leave the bad legacy behind characterized by nationalism, fanaticism, intolerance, hatreds and to come little by little to similar and later on to the common approach toward the future. Thanks to these

\footnotetext{
${ }^{1}$ NATO-North Atlantic Treaty Organisation, Treaty of Washington, 1949

2 United Nations Organisation-1945

${ }^{3}$ Organisation for Security and Cooperation in Europe, 1975

${ }^{4}$ Euroepan Union, Treaty of Lisbon, 2008

${ }^{5}$ Council of Europe, 1949

6 Stability Pact- 1999

${ }^{7}$ Adriatic Charter, 2003
} 
international agreements accompanied by very strong international political, technical, legal, economic and military assistance there is no war in the Balkans, but peace is prevailing entire region.

Peace is prerequisite for democratic and economic development. But it is not enough. Looking into latest developments regionally and individually in the Balkans we can realize that the crisis have been transformed in the different shapes and dimensions but not yet resolved. I am neither skeptics nor euphoric, but trying to be simply realistic. Let me count some latent crisis dealing with the International Agreements concerning the Balkans:

1. "Dayton Peace Accord" ${ }^{1}$ signed by three parties in the conflict and Major Powers brought the bloody war to the end and open a new process of peace making, state building, establishing democratic institutions, parliamentary democracy, rule of law, fundamental freedom and human rights and minority rights for the entire people of $B \& H$. No doubt that these are great achievements. But looking deeply inside reality in B\&H a lot of experts are coming more or less in common conclusions that Country needs much more efforts and international contribution to move to another stage in democratic state-building, political consensus, multi-ethnic dialog and social cohesion. It seems to me that "Dayton Peace Accord" needs little by little to be updated to the new challenges on the ground and to the new phase of Regional development. Internal synergy, positive geopolitical will around the Country and continuing efforts by International Community should bring the $\mathrm{B} \& \mathrm{H}$ to the normal independent, functional and democratic state.

2. "Ohrid Frame Work Agreement" 2 signed by International Community and Macedonian and Albanian, as the three parties agreement, paved way for the democratization of the Independent State of FYROM. This Framework Agreements stopped the internal ethnic and political conflicts between Albanians and Macedonians followed by constitutional and legal changes and improved obviously the atmosphere among the different ethnic communities in FYROM. This Framework Agreement laid fundament for the Country to accelerate the integration process to Euro-Atlantic institutions. But, despite the internal progress, the improving political dialog and ethnic relations are and should be the long term priority for this Country in order to have political stability, ethnic peaceful coexistence and social cohesion. On the other side, the FYROM is facing the serious geopolitical crisis. FYROM and its relations with Greece concerning the Name, with Bulgaria concerning substantial identity components and with Serbia concerning authentic Church and the diplomatic relations with Independent State of Kosovo - unfortunately has created very difficult situation for the Country. I think that all the recent mentioned Countries and FYROM should try together to find the way out from this un-ended vicious crisis.

3. "Ahtisari Final Proposals" 3 as the compromise documents prepared within the Principal Framework Agreement of the Contact Group and the negotiation Team charged by UN Security Council concerning Kosovo crisis were strongly supported internally by the Kosovo people and externally be more then 63 states all over the world to produce the Independent State of Kosovo. This document was the fundament for the new Constitution of the Republic of Kosovo. Despite the fact that Independent State of Kosovo produces peace at home and peace in the Region the situation between Kosovo and Serbia in the border between them is still an open and dangerous crisis. This crisis has no benefit for both sides and reflects negative impact for the entire Region.

Based on the above mentioned International Agreements that brought peace and stability in the Balkans after the Cold War, four main conclusions may draw the attention for the Regional Security to be transformed through Regional Ownership for all Balkan Countries.

First, the International Agreements designed by the International Community with the local factors that I above mentioned are mostly top dawn agreements. In order these agreements to be sufficient as the Regional Ownership they should be transformed as the bottom up acceptance. It means the local factors in the Balkans should accept willingly the principals and the goals of these agreements by transforming those International Agreements into legal instruments and local institutions.

Second, the International Agreements that I above mentioned were mostly agreement coming from abroad. In order these agreements to be as the Regional Ownership they should be promoted from the inside synergy. This inside synergy can

\footnotetext{
1 Dayton Peace Accord, USA, 1995

2 Ohrid Frame Work Agreement, Macedonia, August 2001

${ }^{3}$ Ahtisari Final Proposals, December, 2007
} 
be produced only by very open and intensive political dialogue, inter-ethnic relations, multi-cultural communication and broader social cohesion.

Third, mostly the International Agreements that I above mentioned have been imposed agreements and not as the result of negotiation process of the parties in the war or conflicts. In order these agreements to be transformed as the Regional Ownership, it is prerequisite those agreements to be welcomed by local peoples, local communities, local Parties and institutions, through better understanding, transparent information and public communication.

Fourth, mostly the International Agreements were designed in different times, different Countries and in different formats, having the intention to stop the war and the internal and external conflicts and to open way for peace, security and the democratization in the separate Countries. In order these separate agreements of International Community with different Countries and parties to produce Regional Security through Regional Ownership it is necessary all the Countries in the Region and not only the persons of these International Agreements to move regionally from agreements to realities, from dialogue to concrete common action, from the individual strategies and priorities to the regional approach and from International disengagement to the stronger Regional engagements

\section{References:}

[1] Adriatic Charter, 2003

[2] Ahtisari Final Proposals, December, 2007

[3] Council of Europe, 1949

[4] Dayton Peace Accord, USA, 1995

[5] Euroepan Union, Treaty of Lisbon, 2008

[6] NATO-North Atlantic Treaty Organisation, Treaty of Washington, 1949

[7] Ohrid Frame Work Agreement, Macedonia, August 2001

[8] Organisation for Security and Cooperation in Europe, 1975

[9] Stability Pact- 1999

[10] United Nations Organisation-1945 